\title{
Collecting Mussolini: The Case of the Susmel-Bargellini Collection
}

\section{Susanna Arangio}

University of Ferrara

\begin{abstract}
Heritage Studies has dealt with Italian Fascism in different ways but paying little attention to the movable items linked to the regime, such as paintings, sculptures and memorabilia. Over the last decade, private collections linked to the Mussolini iconography have emerged, owing to a renewed social acceptance of it and more items of Mussoliniana being readily available. Due to the reluctance of experts to confront this issue and the expansion of private museums in Italy, spontaneous initiatives have sprung up including a permanent exhibition of Mussolini iconography as part of the MAGI'900 Museum in Pieve di Cento, which consists of approximately 250 portraits of the Duce in different media. The nucleus of the original collection once belonged to the historian Duilio Susmel and was part of a large documentary collection put together during the 1960s and 1970s. Susmel hoped it would become a museum or a centre for Fascist studies, but ultimately it remained in his private villa near Florence until the 1990s. The archive is now split between Rome and Salò, and the Mussoliniana was purchased by Bargellini, who added busts, paintings and knick-knacks. Since 2009 it has been on display in a section of Bargellini's museum entitled Arte del Ventennio. Therefore, the Italian State tolerates its existence but sadly it is ignored by most experts, despite the study opportunities it offers.
\end{abstract}

Keywords: Mussolini, Susmel, Bargellini Collection, Museum

\section{Introduction}

For several years, Heritage Studies scholars have been considering the problematic heritage of Fascist-era architecture, its external and internal decorations - and the state of abandonment in which many of these find themselves - as well as the way they have been reused since the fall of the regime. While some restoration or enhancement work has been conducted (Billi \& D’Agostino 2017; Carter \& Martin 2017; Hökerberg 2017; Marcello 2019), the debate remains rather heated (Arthurs 2010, 2019; Bartolini 2019; Ben-Ghiat 2017; Carter \& Martin 2019; Malone 2017; Storchi 2019). 
There has been much less attention paid to mobile artefacts pertaining to the Fascist era, such as the memorabilia, paintings and sculptures strictly linked to the regime's propaganda (Pieri 2015). The recent social acceptance of these works, and the easy availability of Mussoliniana online, has revived a type of collecting that is largely characterized by a strong devotional character, which many art historians and museum curators do not want to address. Therefore spontaneous, private initiatives readily available to the public, in which sugar-coated narratives of the former regime are perpetuated, can sometimes lead to genuine acts of exaltation: the extreme example of this is the Casa dei ricordi set up inside Villa Carpena, one of the Mussolini's residences not far from Predappio, where objects and documents are displayed in a way to rehabilitate the cult of the Duce (Casa dei ricordi 2019). In fact, the absence of a national documentation centre for the history of Fascism and a great expansion of private museums in Italy, often managed by non-professionals, involves the risks of private collectors renarrating national public histories through hagiographies based on personal opinions.

In this context, the Susmel-Bargellini collection has been part of the permanent exhibition at the MAGI'900 in Pieve di Cento since 2009 (Arangio 2018a, 2019; Petacco 2009). The MAGI'900 is a private museum founded by the entrepreneur Giulio Bargellini, housed in an old grain silo dating back to the 1930s. The building has enormous symbolic value for the local community and the agrarian history of the province of Bologna and was opened in 1999 under the name of Museo d'arte delle generazioni italiane del '900, hence the acronym "MAGI'900".

The Susmel-Bargellini collection is on the top floor of the museum and is given the generic name Arte del Ventennio on its website (MAGI'900 2019). It is a collection of 250 portraits of Mussolini in different media including sculpture, painting, drawing, mosaic, photography, printing and ceramic, as well as objects made in series such as coins, plaques and ashtrays, and other relics related to Fascist propaganda. The works reflect both 'mass' and 'high' culture and produced by both well- and lesser-known artists, such as artisans or amateurs who depicted the dictator's likeness during and after the Fascist period.

This paper offers a number of key points on the history of this collection and some reflections on its current exhibition.

\section{Duilio Susmel and the Museum of Fascism project}

The Susmel-Bargellini collection was born from the purchase of part of the collection that once belonged to Duilio Susmel, a journalist and historian of Fascism whose work had almost been forgotten. He was also a collector of books, documents, posters, memorabilia and artworks related to the history of Fascism and the Italian Social Republic - but above all to Mussolini. The collection was destined to give birth to a museum and a centre for the study of Fascism, but ultimately remained in the historian's house, constituting a de facto private archive available to anyone who requested it.

The iconographic material is therefore the corollary of a much larger documentary project, corresponding more or less to what an official referred to as a "Museum of Fascism", in 
a report drafted by the Archival Office of Tuscany in 1984 (Borgia 1984). At the time, the collection was composed of 204 pieces stored in a special compartment on the ground floor of Susmel's home, which featured 81 artworks, 58 autographed photographs and 65 other documents. The works of art included

"oil orpastel paintings, drawings on paper and glass, mosaics, carved wooden tondi, ceramic tiles, woodcuts, watercolors, metal reliefs, tapestries, bronze medallions, lithographs, wooden and marble sculptures, wooden and marble busts, bronze tables as well as plaster casts, medals and coins, ornate casings, daggers, decorations, etc." (Borgia 1984).

Examining Susmel's personal correspondence, it was possible to partly retrace the history of the acquisitions that enabled the collection to come together, which cannot be separated from the events of Susmel's professional life as a historian and journalist.

Duilio worked with his father Edoardo on the drafting of the Opera Omnia, a monumental collection of Mussolini's speeches, which he continued after his father's death in 1948 and subsequently published in 44 volumes, over the course of several years (Susmel \& Susmel 1951-1980). The history of the collection is intimately bound up with the writing of these books: the extensive correspondence of the late 1940s and early 1950s shows that Duilio was constantly looking for documents to examine and possibly publish. He had already become relatively proficient at recognizing original documents signed by Mussolini and developed a familiarity with the market for this type of material. However, it seems that he did not yet have the economic means to expand his collection significantly, and it initially had to be composed primarily of what his father had collected during his lifetime. Thanks to the publication of a four-volume biography of Mussolini (Susmel \& Pini 1953, 1954, 1955), Susmel greatly increased the quantity of documents purchased, adding magazines and photographs to the collection. His work as historian and journalist intensified and by the mid-1960s references to a "Fascist archive" housed in the Susmel home became increasingly frequent in his correspondence. The first trace of an effective desire to create a museum and centre for Fascist studies dates back to November 1964, from a dense correspondence with Don Giovanni Antonietti, who possessed a large archive of Fascist figures. Susmel spoke of a "Centre for the study of Fascism and Mussolini", for which he had "a project and very clear ideas" (Susmel to Antonietti, 12 November 1964, in BNCR: A.R.C. 20.71/3.10) in mind:

"With regard to my hopes for a "Study Centre", I must tell you first of all that founding it as an association (which is precisely what should be done), requires no authorization. Secondly, the "Centre" could initially be based here, with me, before moving elsewhere, possibly to Florence. As far as funding is concerned it seems to me that the problem relates to my library, my archives, my subsequent work and future commitments; my idea is as follows. The entirety of my stuff is now worth about 18 million, all of which should make up the constitutive nucleus, as it were - the core - that I would be willing to sell entirely to the "Centre", on the condition that I would be entitled to at least half the proceeds from the sale. I express myself thus not out of greed, but out of necessity and to ensure a minimum level of future security, because once the "Centre" is founded my work would be almost exclusively devoted to it, leaving me with limited opportunities to earn money. Naturally my work would always be free of charge. It would also be understood that thanks to the amount earned from the sale I would cover the initial costs. Of course, once 
the Centre was founded I would approach certain Fascist friends who were able to donate - and with a fair chance of success, given that the "Centre" would already exist; it would be a fait accompli, in other words. However, I think these friends could well donate even now, if they could identify an initial source of funds." (Susmel to Antonietti, 20 November 1964, in BNCR: A.R.C. 20.71/3.12).

This collaborative project fell through due to a disagreement over the legal form the museum should take, and Duilio decided to keep the archive at home, enriching it with drawings and prints depicting Mussolini. This new approach was connected to a book he was working on, Un nomo chiamato Mussolini (Susmel 1973), which was intended as a collector's item with a limited print run and two separate editions - both "luxury" and "extra luxury" - as well as several ad personam editions. He looked for artists to create appropriate illustrations, ${ }^{1}$ but ultimately he used reproductions of artworks from the Fascist period, ${ }^{2}$ including a woodcut by Carlo Guarnieri donated by the artist and now on show at the MAGI'900 (Fig. 1).

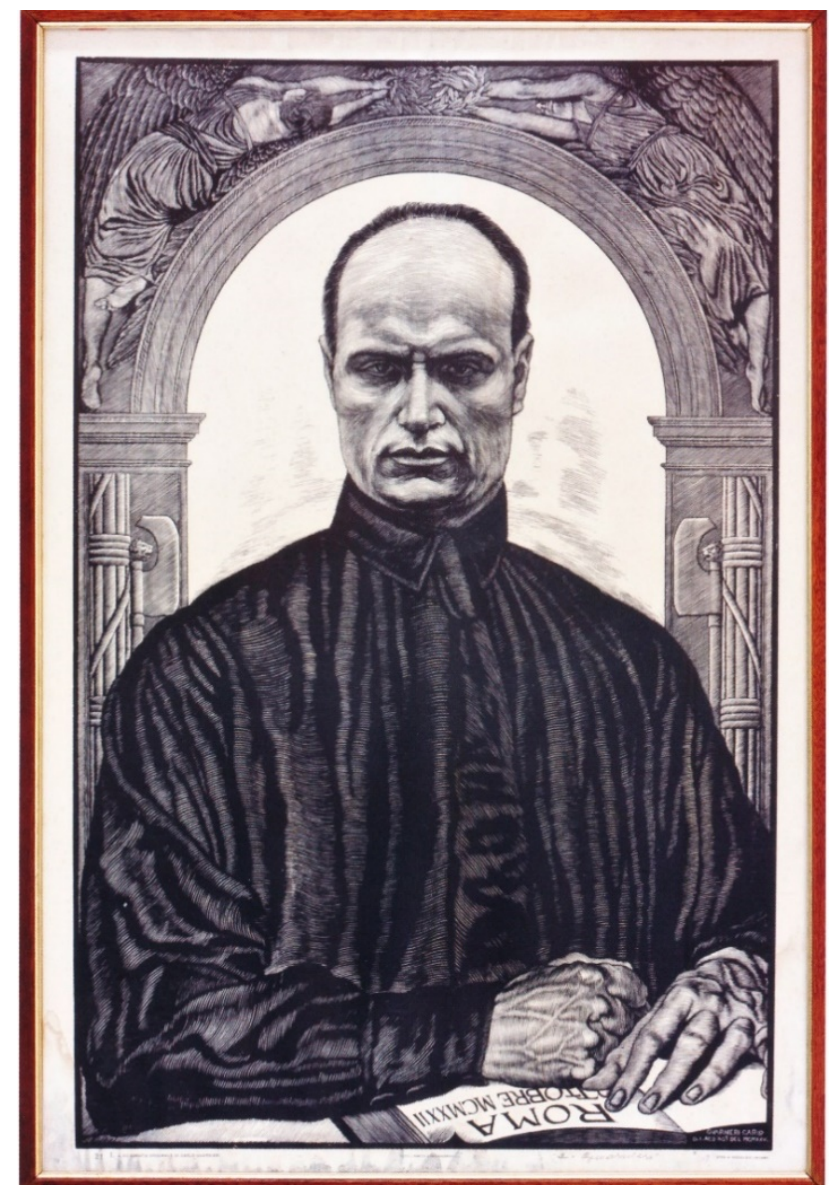

Figure 1. Carlo Guarnieri, Il Capo, woodcut, 1925, cm 57x86, Museo MAGI'900, Pieve di Cento (image credits courtesy of Museo MAGI'900).

\footnotetext{
${ }^{1}$ Susmel had also published another piece entitled $D u x$ for the same publisher around the same time, which is now unobtainable. In the inventory of Susmel's personal archive (ASAT), the text "Mussolini, profili, figure, ritratti" is mentioned among his unpublished works (no publishing house is specified); it is likely that the requests for collaboration sent to certain artists by Susmel also refer to these two texts.

${ }^{2}$ It was not possible to trace the extra luxury and ad personam editions, so we do not know at the moment how they were illustrated.
} 
It is a portrait of the Duce commissioned by the Fascist group "Edoardo Crespi" at the end of 1924 in 1000 copies of which the artist at the time kept 200, while most of them were destroyed (Guarnieri to Susmel, 8 November 1973, BNCR, A.R.C.20.74/15.1). It is therefore a rare work, also because Guarnieri interrupted his xylographer activity in 1928, on the death of his teacher Adolfo de Carolis. This portrait of Mussolini repeats the same pattern found in other works by the artist, who created several literary and historical figures immersed in a neo-Renaissance atmosphere, stylistically characterized by wavy and elegant features similar to those of Symbolism. The date of the March on Rome appears clearly in the book in the foreground.

A commentator of the time writes:

"the left-hand rests on the date; the right hand clenched into a fist, commands. Bust erect under the black shirt, clear imperial face, steady penetrating eyes. Where does Man look? In front, above and beyond" (Orsini G. 1926 quoted in Baldocchi 2009: 30),

The work was particularly appreciated by Susmel, according to whom the artist would have been able to capture the human aspect of Mussolini "better than anyone else" (Susmel to Guarnieri, 28 Dec 1973, BNCR A.R.C.20.74/15.), and is published in his book with the title Il Capo (Susmel 1973: 9).

Susmel collected documentation relating to missing works of art concerning Mussolini ${ }^{3}$ and was also engaged in writing a piece about the Italian Social Republic of Salò, which he never published. At the same time, he was trying to sell his archive and library: he managed to sell just a small part of the archive to the State Archives in Rome in 1974, while the library, which consisted of over 9000 titles, was purchased by the Germanic Institute of Rome in 1976. However, he was never able to reach an agreement with the State Archives in Rome and the Archival Office of Tuscany regarding the sale of the whole archive. He also encountered problems with private individuals, as his main condition for the sale was that the archive should not be split into separate parts.

Although attempts to sell the archive did not go well, Susmel continued to buy memorabilia, works of art and medallions. Among the artefacts purchased at that time, it is interesting to mention a bust of Mussolini made by Pietro Canonica (Fig. 2): it is one of the seven bronze exemplars melted from a plaster bust made available by the sculptor's widow in 1980 (Susmel to Pillon, 6 July 1980, CSRSI: Archivio Susmel, 2.4, folder Canonica). It is a copy of the Mussolini bust displayed at the Canonica's museum from the 1991, when it was found inside a chest kept in a warehouse (Canonica Museum Library, data sheet $C$ 515.), so at Susmel's time the bust was unknow. Its fusion in seven exemplars also suggests that there were six other buyers ${ }^{4}$, revealing something about " $a$ still mostly

\footnotetext{
${ }^{3}$ The Susmel fund kept in the RSI study centre in Salò includes a series entitled Artisti del regime fascista which includes three folders, with a total of 246 files arranged in alphabetical order (CSRSI).

${ }^{4}$ According to the Susmel correspondence, one of them was Giorgio Pillon, the Susmel colleague that acted as an intermediary with the Canonica's widow.
} 
unknown aspect of the history of collecting in Italy" (Pieri 2015: 236). This portrait of Mussolini dates back to 1926 and shows a humanized leader, close to contemporary portraits of aristocratic personalities portrayed by Canonica at that time: the Duce is in a suit and tie like any bourgeois worker, his face is concentrated and slightly contracted, while his eyes are turned towards an imaginary interlocutor.

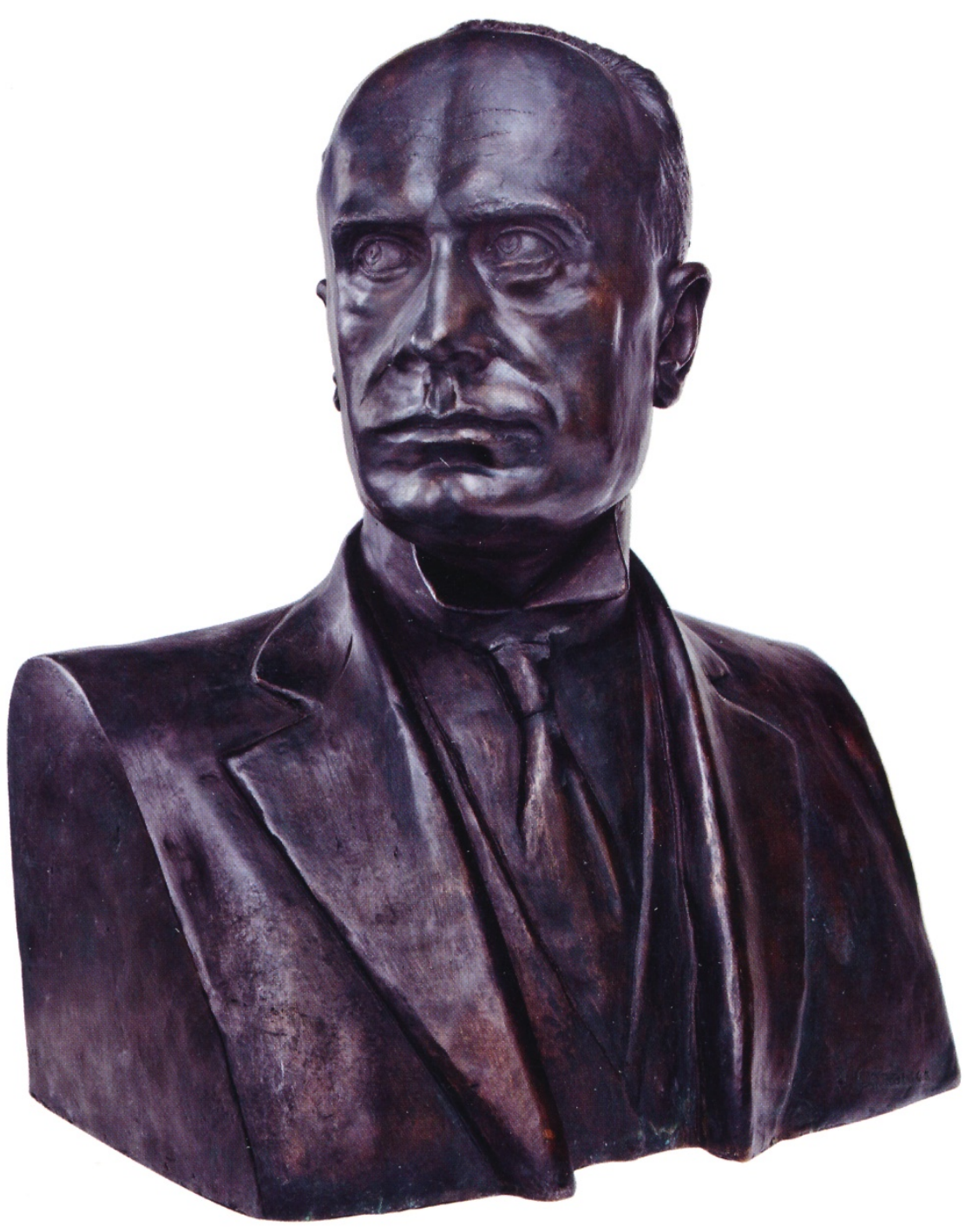

Figure 2. Pietro Canonica, Mussolini, bronze, 1926, cm 43x60x33, Museo MAGI'900, Pieve di Cento (image credits courtesy of Museo MAGI'900).

Duilio Susmel died in 1984 and his archive was declared of historical interest. It was taken over by the Italian Ministry of Culture while the iconographic section was ignored by the Office of Fine Arts and sold to Giulio Bargellini, who claims to have bought the whole collection packaged in boxes, with no inventory attached ${ }^{5}$. Susmel's widow endeavored to

\footnotetext{
${ }^{5}$ Personal conversation with Giulio Bargellini at the Museo Magi'900 in January 2015.
} 
sell the archive throughout her life but did not want to compromise on the price; it was therefore only sold by her heirs and is now divided as follows: the archive relating to the Italian Social Republic is located in Salò, at the RSI Study Centre, while the personal archive, photographs and the Spampanato collection were purchased by the National Library of Rome (Christies 2019).

\section{The Susmel-Bargellini Collection}

After purchasing the Susmel collection, Giulio Bargellini continued to expand it but in a different way: while the historian's archival approach favoured a frenzied accumulation of testimonies concerning the former regime, Bargellini was a pure collector. The additions made by the entrepreneur are mostly identifiable by the busts portraying Mussolini, paintings and knick-knacks, while the Susmel collection was mostly composed of drawings, prints and photographs.

The number of futurist works in the collection has increased: the names of Renato Bertelli (Arangio 2018a: 151-152) and Thayaht (Arangio 2018a: 141-142) stand out both having now been re-evaluated and presented in various temporary exhibitions, as well as a rare painting made by the futurist painter Olga Biglieri, known under the name of Barbara (Petacco 2009, figs. p. 153). She was part of the Futurist movement between 1935, when she met the futurist group of Verona, and 1942, when her husband Ignazio Scurto was sent to war. Thanks to Marinetti, she exhibited at the Venice Biennale in 1938 and from there she attended all the main exhibitions. The painting Sintesi aeropittorica del Duce was exhibited at the Venice Biennale of 1940, and it was defined by Marinetti as "plastically powerful" (Marinetti 1940: 183). On the occasion of that biennial, a portrait competition was organized in which the representation of Mussolini was the pre-eminent subject; Barbara takes up the stylized silhouette of the 'helmeted head' of the Dux of Thayaht, inserting it within an aerial vision with dreamlike features.

Other paintings are of little artistic value and almost all are difficult to date; they are probably works that could be found in any type of public building, and one should not exclude the possibility that in some cases we are looking at modern creations made by non-professional artists.

Susmel also collected other 'relics' from the Fascist period, such us commemorative plaques or medals, along with a number of objects that apparently belonged to Mussolini (a microphone, inkwell and a paper stamp), to which Bargellini added a series of modern, kitsch knick-knacks such as coasters, foulards, ashtrays and small desktop busts. There are also several caricatures of Mussolini by Tono Zancagnaro in the collection, as if to compensate for the broadly devotional intent of the rest of the collection (Arangio 2018a: 146-149).

It is interesting to point out that, despite the fact that the museum contains several works made by well-known artists, as well as rare works made in series, nothing has been borrowed for the ever-increasing number of temporary exhibitions on Fascist-era art 
which have been organized in Italy in recent years (Arangio 2018b). The collection is largely unknown to scholars and art curators, despite most of the works having been published in a paper catalogue (Petacco 2009) and viewable online on the museum's website (MAGI'900 12 Dec 2019). Even at the time of its opening the collection made little impact, and certainly nothing comparable to what happened on the occasion of the first exhibition of Mussolini iconography, inaugurated in the small town of Seravezza in 1997, which was the subject of a parliamentary debate (Oliviero 1997). Despite the provocative intentions of its title, the MAGI'900 'forbidden collection' (Petacco 2009) was mostly ignored and continues to be so for multiple reasons. Yet the peripheral character of the museum only partly justifies the disinterest of experts; the biggest problem is the clearly devotional scope of the collection, which comes across as a sort of private temple dedicated to the worship of the Duce, and from which scholars seek to distance themselves from.

However, this attitude precludes both the possibility of improving the museum and the opportunity to study rare works. In our opinion, several starting points for reflection and in-depth analysis are instead offered by the collection and they would be worthy of greater attention by scholars of various disciplines. In the field of historical-artistic studies, the presence of artworks that could complete the studies of some artists whose work during the regime remains vague cannot be ignored. From the point of view of the history of collecting, it reveals a hidden market that has nevertheless persisted throughout the postwar period to the present day. And besides, the devotional component opens up to multiple reflections, in particular about the marked gap between the achievements of historical researches and the collective memories, where a dangerous 'de-fascist' image of the regime and a widespread feeling of indulgence towards its leader remains. This last aspect has been politically exploited in the case of other controversial figures such as that of Stalin, who was in many ways rehabilitated in the era of Brezhnev's 'developed socialism'. Moreover,

"around Moscow it is very easy to come across busts, statues, monuments and plaques dedicated to Lenin and the Communist leaders and it is interesting to note that there has been a policy aimed at the preservation of these symbols" (Cucciolla 2020).

On the contrary in Italy the lack of sustained State research around the public material culture of Fascism and a popular rehabilitation of its leader encouraged by some far-right parties is favouring private initiatives such as that of Bargellini.

On the other hand, some of the MAGI'900 problems are common to those of other private cultural institutions in Italy. With this in mind, it is worth remembering the proliferation of private initiatives in the peninsula: according to an international census carried out in 2016 (Bouchara 2016), 19 private collectors decided to make their collections public and accessible by creating a museum, putting Italy in fifth place worldwide and second in Europe (Maggi 2016). Although this survey refers only to a small part of the collections currently present in Italy, focusing on those of contemporary art collected by living collectors, it is important to understand a trend that peaked between 
2001 and 2011, a period in which private museums constituted a significant 69 percent of the total. This proliferation of private museums has not always been accompanied by adequate professionalism; the inherent risk of a museum founded by a living collector is that it may become an extension of their personality. This is one of the main problems of the museum in Pieve di Cento: although Giulio Bargellini has worked with art historians and curators since its foundation, there is no denying that the museum suffers from various problems that would be difficult to resolve without bypassing the will of its owner. Looking at the Mussolini iconography collection specifically, there are problems related to the lack of cataloguing of the works, in addition to museographic problems, insofar as the collection currently on display clearly reflects both the political faith of its owner and a lack of definite planning. Centered on the cult of the dictator's personality, the nature of the collection highlights important problems that only partially approach the solutions put forward by other museums that have portraits of the Duce.

At the Wolfsoniana in Genoa, for example, similar portraits are displayed in the context of other works of the period, above all in order to narrate the history of the art and culture of the time; similarly, their political and propagandistic meaning has been dealt with only in the context of temporary exhibitions organized outside the museum, or in publications (Fochessati \& Franzone 2016). The breadth of the Genoese collection also allows for different exhibition formulas that would hardly be viable at the MAGI'900, which remains unique in both the Italian and international landscape.

\section{Conclusion}

When Susmel decided to keep his collection at home, he wrote:

"This sad communist Italy will never, ever recognize a "Centre for the Study of Mussolini and Fascism". To think otherwise would be to delude oneself into being able to achieve some kind of official recognition; it would mean not acknowledging the reality of things. [...] What needs to be founded is a private association, a kind of private club or institute [...]. And perhaps in half a century it could be transformed into a "National Foundation": when there will be no memory of the caste that governs us today, in other words; when the hatred, resentment and passions will have entirely - or almost entirely - died away" (Susmel to Antonietti, 29 Nov1964, BNCR: A.R.C. 20.71/3.14).

Words like this have turned out to be anachronistic, and the situation is certainly different today. However, there is as yet no museum or centre for the study of Fascism in Italy, and a substantial part of the Susmel archives is hardly accessible. The National Library of Rome did not create a description of the documents but only a very long list, and the access rules to the collection of documents are very strict. In Salò the Susmel archive is described in detail but the library is only open two hours a week. Finally, the Bargellini collection is not what Susmel had hoped to achieve with his collection of Mussolini iconography: it has been decontextualized from the documentary material to which it was associated and is largely unknown or ignored. 
One of the reasons for this is the generalized attitude of scholars and museum curators towards Fascist artefacts, which is often ambiguous and circumvents the problem of their difficult heritage. Both in recent modern art gallery shows and temporary exhibitions covering the period between the two world wars, the political message behind Fascist artefacts such as portraits of Mussolini is often discarded in favour of a more reassuring, formalistic reading; or, alternatively, the artworks are analyzed in the same way as any other historical document, putting aside their role in the history of art. In most cases the preference is to exhibit works that are already known or not iconic, such as those associated with the Futurist movement, while many others remain in museum depots, in ministry cellars or in private collections (Arangio 2018b). These circumstances partly reflect the Italian academic and museological situation, which is traditionally not inclined towards interdisciplinarity; as well as the tendency, still prevalent, towards a "vertical" study of twentieth century art history. This has led to the exclusion of artefacts considered to be of low quality, which are classified in a generic sub-category of 'propaganda art' and/or often dismissed as 'Fascist rubbish'.

We need to consider the Italians' controversial relationship with the Fascist legacy: although Fascism has been the subject of study by academics for decades, there is also a persistent, collective indulgence with regard to how the regime is remembered, one encouraged in particular by the Italian right-wing parties and press. Apparently, portraits of Mussolini remain a symbol for some far-right formations and we are not yet prepared to confront them dispassionately in Italy.

As a result, the Susmel-Bargellini collection currently exhibited at the Pieve di Cento museum remains tolerated by the Italian State at the same time as it is ignored by scholars. The hope would be for a reorganization of the current collection to weaken its devotional character, in favour of a more historical approach; that kind of work would make it possible to explore its potential for further study.

\section{References}

Arangio S. 2018a. La collerione Susmel-Bargellini al Museo MAGI'900 di Pieve di Cento. Doctoral Research Thesis submitted to the University of Ferrara.

ARANGIO S. 2018b. L'iconografia mussoliniana. Un percorso tra rimozioni e riscoperte nelle mostre italiane dal secondo dopoguerra ad oggi, in: M. DANTINI (eds.), Continuità | discontinuità nella storia dell'arte e della cultura italiane del Novecento. Arti visive, società e politica tra fascismo e neoavanguardie. Piano b. Arti e culture visive 3(1): 52-85.

ArAngIO S. 2019. Iconografia mussoliniana e musei: il caso della collezione SusmelBargellini, in: E. HÉRY, C. PANE \& C. PIRISINO (eds.), Mémoire du Ventennio. Représentations et enjeux mémoriels du régime fasciste de 1945 à aujourd'bui. Cinéma, théatre, arts plastiques. Actes du colloque tenu les 15 et 16 septembre 2016 à l'INHA, Paris. Paris: Chemin de tr@verse: 247259.

ARTHurs J. 2010. Fascism as "Heritage" in Contemporary Italy, in: A. MAMMONE \& G.A. VELTRI (eds.), Italy Today: The Sick Man of Europe. Abingdon: Routledge: 207-230. 
ArThurs J. 2019. The Anatomy of Controversy, from Charlottesville to Rome, in: N. CARTER \& S. MARTIN (eds.), Special issue: The Difficult Heritage of Italian Fascism. Modern Italy, 24 (2): 123-138.

BALDOCCHI A. 2009. Mussolini. La marcia su Roma: xilografia di Carlo Guarnieri disegnata e incisa nell'agosto 1925 a cura del Gruppo Fascista Edoardo Crespi. Piombino: La Bancarella Editrice.

BARTOLINi F. 2019. Dealing with a Dictatorial Past: Fascist Monuments and Conflicting Memory in Contemporary Italy, in: L. MACALuso (ed.), Monument Culture: International Perspectives on the Future of Monuments in a Changing World. London: Rowman \& Littlefield: 233-242.

Ben-Ghiat R. 2017. Why Are So Many Fascist Monuments Still Standing in Italy? New Yorker. Accessed 12/10/2020.

https://www.newyorker.com/culture/culture-desk/why-are-so-many-fascistmonuments-still-standing-in-italy

Billi E. \& D’Agostino L. 2017. Sironi svelato: il restauro del murale della Sapienza. Roma: Campisano.

Biblioteca Nazionale Centrale di Roma (BNCR), Fondo Susmel, A.R.C.20.

BORGIA L. 1984. Relazione del sopralluogo effettuato dai funzionari della Soprintendenza Archivistica della Toscana presso il villino Susmel il 28 agosto 1984, Archivio della Soprintendenza Archivisitca per la Toscana: folder V.21.2.

Bouchara C. 2016. Private Art Museum Report. Nürnberg: Modern Art Publishing.

CARTER N. \& Martin S. 2017. The Management and Memory of Fascist Monumental Art in Postwar and Contemporary Italy: The Case of Luigi Montanarini's Apotheosis of Fascism. Modern Italy 22(3): 338-364.

Carter N. \& Martin S. 2019. Dealing with Difficult Heritage: Italy and the Material Legacies of Fascism, in: N. CARTER \& S. MARTIN (eds.), Special issue: The Difficult Heritage of Italian Fascism. Modern Italy 24(2): 117-122.

CASA DEI RICORDI 2019. http://www.casadeiricordi.it/ Accessed 3 Sept 2019.

Centro Studi Repubblica Sociale Italiana (CSRSI). Artisti del regime fascista, Archivio Duilio Susmel, 2.4

Christies 2019. Christies.com (Storia del Fascismo) Archivio Susmel.

http:/ /www.christies.com/lotfinder/Lot/storia-del-fascismo-archivio-susmel-per-

977099-details.aspx Accessed on 14 Dec 2019.

Cucciolla R. 2020. Guerra di statue, anche in Russia. Da Stalin a Putin, breve cronistoria. Formiche.net. https://formiche.net/2020/06/guerra-di-statue-russia/ Accessed 01 Oct 2020.

Fochessati M. \& Franzone G. 2016. L"uomo nuovo" del fascismo, in: M. FOCHESSATI \& G. FrANZONE (eds.) La Wolfsoniana. Immagini e storie del Novecento. Genova: Sagep editori: $127-131$.

HöKerberg H. 2017. The Monument to Victory in Bolzano: Desacralisation of a Fascist Relic. International Journal of Heritage Studies 23 (8): 759-774.

Magi900 2019. MuseoMagi900.com, Arte del Ventennio. Accessed 12 Dec 2019. http://www.magi900.com/le-collezioni/arte-del-ventennio/

MAGGI N. 2016. Musei privati: L'Italia è al secondo posto in Europa. Collezione da Tiffany. https://www.collezionedatiffany.com/italia-musei-privati-2016/. Accessed 2 Oct 2017. 
Malone H. 2017. Legacies of Fascism: Architecture, Heritage and Memory in Contemporary Italy. Modern Italy 22(4): 445-470.

Marcello F. 2019. Between Censure and Celebration: The Decorative Plan of the Casa Madre dei Mutilati in Rome (1926-1939), in: N. CARTER \& S. MARTIN (eds.), Special issue: The Difficult Heritage of Italian Fascism. Modern Italy 24(2): 178-198.

MARINETTI E. T. (1940). Gli aeroritratti del duce. Meridiano di Roma.

Oliviero D. 1997. Interrogazione a risposta scritta 4/11791. Camera dei deputati http://dati.camera.it/ocd/aic.rdf/aic4_11791_13. Accessed 2 Feb 2018.

PetAcco A. 2009. Mussolini ritrovato: storia di una collezione proibita. Argelato: Minerva.

Pieri G. 2015. The Destiny of the Art and Artefacts, in: S. Gundle, C. DugGan \& G. PIERI (eds.), The Cult of the Duce. Mussolini and the Italians. Manchester: Manchester University Press: 227-240.

STORCHI S. 2019. The ex-Casa del Fascio in Predappio and the Question of the "Difficult Heritage" of Fascism in Contemporary Italy, in: N. CARTER \& S. MARTIN (eds.), Special issue: The Difficult Heritage of Italian Fascism. Modern Italy 24(2): 139-157.

Susmel D. \& Susmel E. 1951-1980. Opera Omnia di Benito Mussolini. Firenze: La Fenice.

Susmel D. \& PINI G. 1953, 1954, 1955. Mussolini: l'uomo e l'opera. Four volumes: Dal socialismo al fascismo:(1883-1919); Dal fascismo alla dittatura:(1919-1925); Dalla dittatura all'impero:(1925-1938); Dall'Impero alla Repubblica (1938-1945). Firenze: La Fenice.

SuSMEL D. 1973. Un nomo chiamato Mussolini. Roma: Dino Editori. 